\title{
Erratum to: New Australian population scoring coefficients \\ for the old version of the SF-36 and SF-12 health status questionnaires
}

\author{
Graeme Tucker $\cdot$ Robert Adams $\cdot$ David Wilson
}

Published online: 8 June 2010

(C) Springer Science+Business Media B.V. 2010

\section{Erratum to: Qual Life Res}

DOI 10.1007/s11136-010-9658-9

There were errors in the SF-12 scoring parameters specified in the last paragraph of page 4 in the original publication, and consequently in the two equations following the remainder of the paragraph, on page 5 .

The correct values and equations are shown here. p. 4, last para, line 2: '3.4296' should be '3.2759'

p. 4, last para, line 3: ' 0.59965 ' should be ' 0.54945 '

p. 4, last para, line 4: '3.9489' should be ' 3.8956 '

p. 4, last para, line 4: '0.69260' should be '0.67927'

The equations on page 5 should read:

$\mathrm{SF} 12 \mathrm{PCS}=50+(\mathrm{SF} 12 \mathrm{PCS}-3.2759) \times 10 / 0.54945$

$\mathrm{SF} 12 \mathrm{MCS}=50+(\mathrm{SF} 12 \mathrm{MCS}-3.8956) \times 10 / 0.67927$

The online version of the original article can be found under doi:10.1007/s11136-010-9658-9.

G. Tucker $(\square) \cdot$ R. Adams $\cdot$ D. Wilson Department of Health, Adelaide, SA, Australia

e-mail: Graeme.Tucker@health.sa.gov.au 